\begin{tabular}{|l|l|l||}
\hline \multicolumn{2}{|c|}{ PublisherInfo } \\
\hline \hline PublisherName & $:$ & BioMed Central \\
\hline \hline PublisherLocation & $:$ & London \\
\hline \hline PublisherImprintName & $:$ & BioMed Central \\
\hline \hline
\end{tabular}

\title{
Eat the dead
}

\begin{tabular}{|l|l|l||}
\hline \multicolumn{2}{|c|}{ ArticleInfo } \\
\hline \hline ArticleID & $:$ & 3679 \\
\hline \hline ArticleDOI & $:$ & $10.1186 /$ gb-spotlight-20000508-03 \\
\hline \hline ArticleCitationID & $:$ & spotlight-20000508-03 \\
\hline \hline ArticleSequenceNumber & $:$ & 116 \\
\hline \hline ArticleCategory & $:$ & Research news \\
\hline \hline ArticleFirstPage & $:$ & 1 \\
\hline \hline ArticleLastPage & $:$ & 2 \\
\hline \hline & & RegistrationDate : 2000-05-08 \\
ArticleHistory & $:$ & OnlineDate $\quad$ 2000-05-08 \\
\hline \hline ArticleCopyright & $:$ & BioMed Central Ltd2000 \\
\hline \hline ArticleGrants & $:$ & \\
\hline \hline ArticleContext & $:$ & 130591111 \\
\hline \hline
\end{tabular}




\section{William Wells}

Email: wells@biotext.com

Apoptosis eliminates the asymmetry of plasma membrane phospholipids and exposes phosphatidylserine on the outside of cells. Fadok et al. report in the May 4 Nature that they have found a phagocyte protein that recognizes the phosphatidylserine (Nature 2000, 405:85-90). Addition of the receptor to lymphocytes allows the cells to engulf apoptotic cells. Engagement of the receptor on macrophages induces the production of anti-inflammatory TGF-b consistent with the absence of inflammation during apoptosis.

\section{References}

1. Exposure of phosphatidylserine on the surface of apoptotic lymphocytes triggers specific recognition and removal by macrophages.

2. Nature magazine's homepage, [http://www.nature.com/nature/]

This PDF file was created after publication. 